\title{
Pemisahan Anomali Regional dan Residual Data Gayaberat Studi Kasus di Kota Lama Semarang
}

\author{
Supriyadi*, Khumaedi, Sugiyanto, dan F. Setiaswan \\ Program Studi Fisika Universitas Negeri Semarang \\ *email: supriyadi@mail.unnes.ac.id
}

Received: July 24th, 2019. Accepted: August27th, 2019. Published: August 29th, 2019

\begin{abstract}
Abstrak
Telah dilakukan penelitian dengan menggunakan metode gayaberat untuk mengidentifikasi struktur bawah permukaan di Kawasan Kota Lama Semarang sebagai survei awal untuk keperluan mitigasi bencana. Pengolahan data gayaberat untuk mengidentifikasi struktur bawah permukaan dilakukan melalui beberapa tahapan. Tahap awal dilakukan dengan koreksi awal berupa koreksi pasang surut dan koreksi apungan, kemudian dilakukan koreksi lanjut hingga didapat kontur anomali Bouguer lengkap. Melalui anomali Bouguer lengkap dapat dipisahkan anomali gaya berat regional dan residual. Pemisahan anomali regional dari anomali Bouguer dalam penelitian ini menggunakan metode moving average (perata-rataan bergerak) sedangkan anomali residual didapatkan dengan cara mengurangkan anomali Bouguer dengan anomali regional. Pemisahan anomali regional dan residual penting untuk dilakukan pada penelitian identifikasi struktur bawah permukaan untuk menginterpretasikan struktur geologi dan mendapatkan target yang dicari. Nilai anomali regional di Kawasan Kota Lama Semarang antara 28.0 mGal - 28.4 $\mathrm{mGal}$ sedangkan untuk anomali residual memiliki antara $31.6 \mathrm{mGal}-32.8 \mathrm{mGal}$.
\end{abstract}




\begin{abstract}
Research has been carried out using gravity methods to identify subsurface structures in the region of Kota Lama Semarang as a preliminary survey for disaster mitigation purposes. In processing gravity data to identify subsurface structures, several processing stages are carried out. The initial step is to make the initial correction in the form of tide correction and float correction then a further correction is performed until a complete Bouguer anomaly contour is obtained. From the complete Bouguer anomaly, regional and residual gravity anomalies can be separated. The separation of regional anomalies from Bouguer anomalies in this study uses the moving average method while residual anomalies are obtained by subtracting Bouguer anomalies from regional anomalies. In the study of identification of subsurface structures it is important to conduct regional and residual anomaly separations to interpret geological structures and obtain the targets sought. Regional anomaly values in the region of Kota Lama Semarang are between $28.0 \mathrm{mGal}$ - $28.4 \mathrm{mGal}$ while for residual anomalies have between $31.6 \mathrm{mGal}$ - $32.8 \mathrm{mGal}$. (2019PERJ
\end{abstract}

Keywords: gravity, Old City Semarang, residual anomaly. 


\section{PENDAHULUAN}

Gayaberat merupakan salah metode dalam eksplorasi geofisika. Anomali yang terukur di bawah permukaan dalam kegiatan ekplorasi gayaberat merupakan superposisi dari berbagai sumber anomali yang terdeteksi atau terbaca oleh alat. Target eksplorasi dalam penelitian untuk mengidentifikasi struktur bawah permukaan yaitu anomali residual yang memberikan berbagai informasi mengenai struktur bawah permukaan, kondisi geologi, serta bahan-bahan tambang. Anomali lain yang didapat yaitu anomali regional dan noise. Anomali regional merupakan anomali yang memliki cakupan yang lebar dibandingkan dengan anomali residual.

Berdasarkan kedalamannya, anomali regional merupakan anomali yang lebih dalam dibandingkan anomali residual dan noise lebih dangkal dibandingkan anomali residual. Anomali residual diakibatkan oleh anomali dangkal yang memiliki frekuensi tinggi dan panjang gelombang yang pendek sedangkan anomali regional diakbatkan oleh anomali dalam yang memliki frekuensi rendah dan panjang gelombang yang panjang (Telford et al., 1990).

Pemisahan anomali regional dan residual diperlukan untuk interpretasi struktur bawah permukaan yang dapat dilakukan dengan berbagai metode (cara). Beberapa eksplorasi gayaberat dengan beragam metode pemisahan anomali regional dan residual dapat dilihat di antaranya pada penelitian Shandini dan Tadjou (2012), Purnomo et al. (2013), dan Karunianto et al. (2017).

Metode Moving Average (peratarataan bergerak) dipilih dalam penelitian ini untuk pemisahan anomali regional dan residual. Pada metode ini, pemisahan dilakukan dengan cara merata-rata nilai anomali Bouguer. Hasil dari rata-rata merupakan anomali regional, sedangkan anomali residual didapat dari selisih anomali Bouguer dengan anomali regional (Abdelrahman, 1996).

Eksplorasi geofisika di beberapa wilayah di Semarang telah dilakukan. Beberapa di antaranya dilakukan oleh Imam dan Supriyadi (2014), Wardhana et al. (2014), serta Pryambodo dan Supriyadi (2017). Kota Lama merupakan kawasan pariwisata di Semarang yang telah ditetapkan oleh Pemerintah Kota Semarang dan menjadi tujuan wisata. Terdapat bangunan kuno bergaya Eropa Belanda yang berdiri di kawasan ini. Akan tetapi, penelitian mengenai struktur bawah permukaan di Kota Lama masih jarang dilakukan. Supriyadi et al. (2019) telah melakukan penelitian mengenai penurunan muka air tanah di kawasan Kota 
Lama menggunkan metode gayaberat. Kota Lama termasuk daerah bagian utara kota semarang dengan kondisi geologi tanah berada di formasi aluvium (Wardhana et al., 2014). Pada penelitian ini dilakukan pemisahan anomali regional dan residual studi kasus di Kawasan Kota Lama untuk membantu dalam mengidentifikasi struktur bawah permukaan di Kawasan tersebut.

\section{METODE}

Pengukuran dilakukan pada 75 titik pengukuran yang tersebar merata di Kawasan Kota Lama selama 3 hari. Alat yang di gunakan yaitu gravimeter Scintrex CG-5 Autograv yang memliki ketelitian hingga $1 \mu$ gal dan GPS merk garmin. Software Microsoft Excel digunakan untuk melakukan olah data serta koreksi dan software Oasis Montaj 6.4.2 untuk membantu pengolahan dalam pemisahan anomali.

Data yang terukur dalam alat gravimeter dikoreksi awal pasang surut dan koreksi apungan. Data yang telah dikoreksi kemudian diolah untuk mendapatkan nilai anomali Bouguer lengkap dengan cara melakukan koreksi lanjut berupa koreksi lintang, koreksi medan, serta koreksi ketinggian. Koreksi ketinggian meliputi koreksi udara bebas dan koreksi
Bouguer. Koreksi lintang dilakukan untuk mendapatkan nilai gayaberat teoritis. Koreksi medan tidak dilakukan dalam penelitian ini karena daerah penelitian yang dianggap datar. Koreksi ketinggian berupa koreksi udara yang secara matematis dinyatakan oleh Persamaan 1.

$$
F A C=0,3086 h
$$

dengan $h$ adalah ketinggian dari permukaan laut ke titik pengukuran. Nilai tersebut kemudian digunakan untuk menentukan anomali udara bebas sesuai Persamaan 2.

$$
\Delta g=g o b s-\left(g_{\theta}-F A C\right)
$$

$\Delta g$ menunjukkan anomali udara bebas di topografi. Koreksi Bouguer diperoleh melalui Persamaan 3.

$$
K B=0,04191 \rho h .
$$

Setelah dilakukan koreksikoreksi data gayaberat maka diperoleh anomali Bouguer lengkap yang merupakan hasil superposisi dari komponen regional dan residual. Kedua anomali tersebut saling berinteraksi dan menimbulkan anomali yang tumpang tindih (Purnomo et al., 2013). Sebelum dilakukan pemisahan anomali regional dan residual, anomali Bouguer lengkap perlu dianalisis spektrumnya untuk mengetahui estimasi kedalaman regional dan residualnya serta untuk 
mendapatkan lebar jendela untuk proses filter moving average.

Proses analisis spektrum biasanya dilakukan dalam satu dimensi. Pada analisis spektrum dilakukan transformasi Fourier untuk mengubah sinyal menjadi penjumlahan beberapa sinyal. proses transformasi Fourier mengubah domain waktu atau spasial ke domain frekuensi atau bilangan gelombang $(k)$. Melalui analisis bilangan gelombang $(k)$ dan amplitudo $(A)$, estimasi kedalaman anomali regional dan residual dapat diperkirakan serta dapat ditemukan lebar jendela filter dari perhitungan frekuensi cut off dari analisis spektrum.

Transformasi Fourier untuk penampang 1D data anomali Bouger yang diturunkan oleh Blakely (1995) dapat dilihat pada Persamaan 4.

$$
F(k)=\int_{-\infty}^{\infty} f(x) e^{-i k x} d x
$$

dengan $k$ merupakan bilangan gelombang terhadap panjang gelombang $\lambda$ atau frekuensi $f$, yang nilainya dapat ditentukan melalui Persamaan 5.

$$
k=\frac{2 \pi}{\lambda}
$$

Nilai $k$ dan amplitudo yang didapat kemudian digunakan untuk menentukan lebar jendela dalam proses filter moving average.
Proses filter moving average secara matematis dapat dituliskan seperti pada Persamaan 6:

$$
\Delta g_{R}(i)=\frac{\Delta g(i-n)+\cdots+\Delta g(i)+\cdots+\Delta g(i+n)}{N}
$$

dengan $\Delta g_{R}$ merupakan anomali regional, $n=(N-1) / 2$ dan $N$ adalah lebar jendela. Nilai $N$ harus bilangan ganjil. Contoh aplikasi moving average pada data 2D dengan jendela $5 \times 5$ ditunjukkan pada Gambar 1.

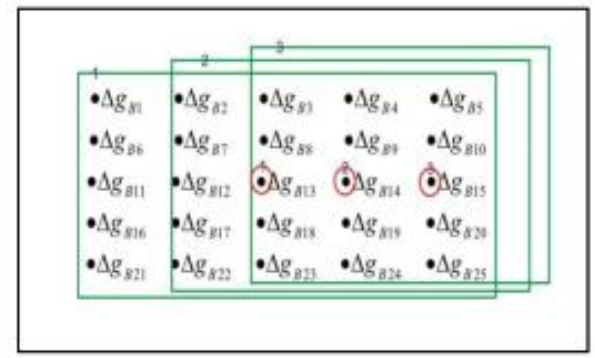

Gambar 1. Ilustrasi Moving Average 2D jendela $5 \times 5$

\section{HASIL DAN PEMBAHASAN}

Hasil dari pengolahan data gayaberat menggunakan software Oasis Montaj di Kawasan Kota Lama Semarang diperoleh gambaran peta anomali bouguer lengkap yang ditunjukkan pada Gambar 2. 


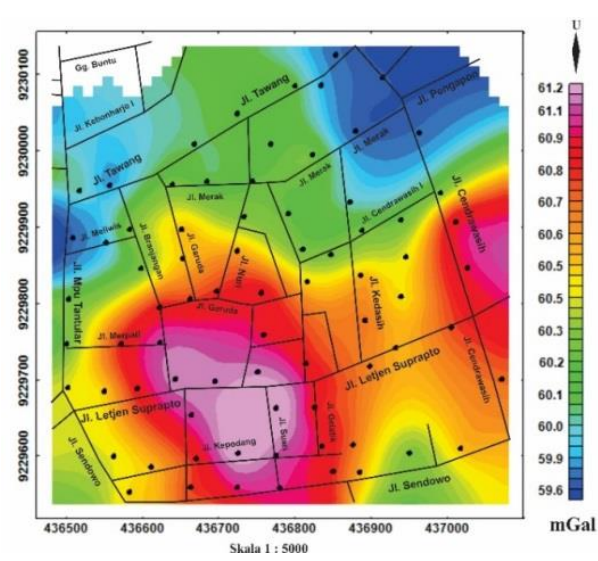

Gambar 2. Peta Anomali Bouguer Lengkap Kota Lama Semarang

Gambar 2 menunjukkan anomali Bouguer lengkap hasil pengolahan dari data terukur di Kota Lama Semarang dengan nilai antara 59.6 hingga $61.2 \mathrm{mGal}$. Anomali rendah ditunjukkan oleh warna biru yang terkonsentrasi di sebelah utara sekitar Jalan Pengapon, sedangkan anomali tinggi ditunjukkan oleh warna merah hingga merah muda yang berada di sekitar Jalan Kepodang, Suari, dan sebagian Jalan Letjen Suprapto. Anomali yang tinggi mengindikasikan struktur batuan dengan densitas yang tinggi dibanding daerah sekitarnya, dan sebaliknya anomali yang rendah memiliki struktur batuan dengan densitas yang rendah.

Anomali gayaberat yang terukur di lapangan merupakan gabungan dari anomali regional dan residual yang dapat dipisahkan dengan menggunakan metode moving average. Tujuan dari pemisahan anomali yaitu untuk mendapakan sumber anomali dari regional dan residual.

Melalui metode moving average yang di gunakan dalam penelitian ini diperoleh anomali regional yang ditunjukkan pada Gambar 3, sedangkan untuk mendapatkan anomali residual (anomali dangkal) dapat dilakukan dengan cara mengurangkan anomali Bouguer lengkap dengan anomali regional yang dilihat pada Gambar 4.

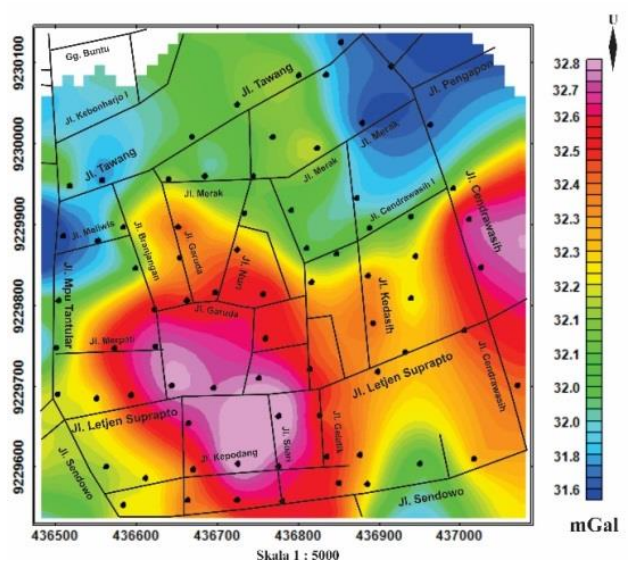

Gambar 3. Peta Anomali Regional
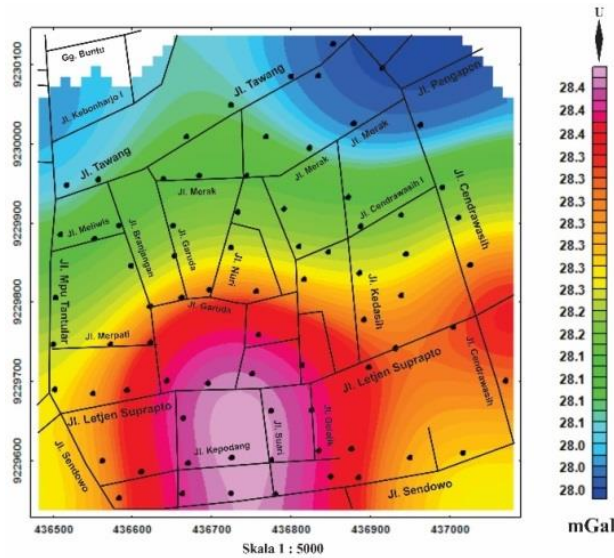

Gambar 4. Peta Anomali Residual 
Gambar 3 menunjukkan nilai sebaran anomali tinggi dan anomali rendah. Nilai anomali regional yang rendah berada di bagian utara daerah penelitian (Jalan Tawang) di tunjukkan oleh warna biru dengan nilai antara 28.0 sampai 28.1 mGal. Bagian tengah memiliki nilai anomali sedang yang hampir merata ke arah selatan dengan rentang 28.1 sampai $28.3 \mathrm{mGal}$. Nilai anomali tinggi ditunjukkan di sekitar Jalan Kepodang yang berwarna merah sampai merah muda yang memiliki nilai anomali antara 28.3 sampai $28.4 \mathrm{mGal}$.

Gambar 4 menunjukkan sebaran nilai anomali tinggi dan rendah di daerah penelitian dengan rentang antara 31.6 sampai $32.8 \mathrm{mGal}$. Anomali rendah berada di bagian utara daerah penelitian di sekitar Jalan Pengapon yang ditunjukkan oleh warna biru dengan rentang nilai 31.6 sampai 32.0 mGal; sedangkan di bagian tengah terdapat anomali yang tinggi yang ditunjukkan oleh warna merah dengan rentang nilai 32.6 hingga $32.8 \mathrm{mGal}$.

Hasil pengolahan data gayaberat berupa peta anomali regional dan residual selanjutnya dapat digunakan untuk menganalisis struktur bawah permukaan dengan berbagai macam metode analisa geologi seperti First Horizontal Derrivative (FHD) dan Second Vertical Derrivative (SVD).

\section{REFERENSI}

Abdelrahman. 1996. Shape and depth solutions from moving average residual gravity anomalies. Egypt: Journal of Applied Geophysics, 36, 89-95.

Imam, S. dan Supriyadi. 2014. Unnes Physics Journal. Unnes Physics Journal, 3(1).

Karunianto, A. J., Haryanto, D., Hikmatullah, F., dan Laesanpura, A. 2017. Penentuan Anomali

Gayaberat Regional dan Residual Menggunakan Filter Gaussian Daerah Mamuju, Sulawesi Barat. Eksplorium, 38(2), 89-98.

Pryambodo, D. G. dan Supriyadi. 2017. Zonasi Penurunan Muka Air Tanah di Wilayah Pesisir Berdasarkan Teknik Geofisika Gayaberat Mikro 4d (Studi Kasus: Daerah Industri Kaligawe- Semarang). Jurnal Kelautan Nasional, 10(3), 151162.

Purnomo, J., Koesuma, S., dan Yunianto, M. 2013. Pemisahan Anomali Regional Residual pada Metode Gravitasi menggunakan Metode Moving Average, Polynomial, dan Inversion. Indonesian Journal of Applied Physics, 3(10), 10-20.

Purnomo, Jarot, Koesuma, S., dan Yunianto, M. 2013. Pemisahan Anomali Regional-Residual pada Metode Gravitasi 
Menggunakan

Metode

Moving Average, Polynomial dan Inversion. Indonesian Journal of Applied Physics, 3(1), 10-18.

Shandini, Y., dan Tadjou, J. M. 2012. Interpreting gravity anomalies in south Cameroon , Central Africa. Earth Sciences Research Journal, 16(1), 5-9.

Supriyadi, Khumaedi, Sugiyanto, dan Ikhsan, M. 2019. Kajian Dinamika Muka Airtanah di Kawasan Kota Lama Semarang Menggunakan Metode Mikrogravitasi Antar Waktu. Jurnal Risalah Fisika, 3(1).
Telford, W. M., Geldart, L. P., dan Sheriff, R. E. 1990. Applied Geophysics Second Edition. Cambridge: Cambridge University Press.

Wardhana, D. D, Harjono, H., dan Sudaryanto. 2014. Subsurface Structure of Semarang City Based on Gravity Data. Jurnal RISET Geologi dan Pertambangan, 24(1), 53-64.

Wardhana, D. D., Harjono, H., dan Sudaryanto. 2014. Struktur Bawah Permukaan Kota Semarang Berdasarkan Data Gayaberat. Jurnal RISET Geologi dan Pertambangan, 24(1), 53-64. 